\title{
Pelatihan Praktik Kerja Audit (Kualitas Audit) oleh Kantor Akuntan Publik (KAP) bagi Mahasiswa Jurusan Akuntansi Fakultas Ekonomi Universitas Sriwijaya
}

\author{
Efva Octavina Donata Gozali ${ }^{1 *}$, Yusnaini $^{1}$, Ruth Samantha Hamzah ${ }^{1}$ dan Nur Khamisah ${ }^{1}$ \\ ${ }^{1}$ Fakultas Ekonomi, Universitas Sriwijaya, Sumatera Selatan, Indonesia \\ *Email korespondensi: efvagozali@unsri.ac.id
}

Info Artikel: Diterima: 12 November 2020; Disetujui: 08 April 2021; Dipublikasi: 10 Mei 2021

\begin{abstract}
Abstrak: Kegiatan pengabdian ini ditujukan kepada mahasiswa jurusan Akuntansi Fakultas Ekonomi Universitas Sriwijaya kekhususan audit dalam bentuk pelatihan praktik kerja auditor yang dihubungkan dengan indikator-indikator dari kualitas audit. Tujuan dari kegiatan pengabdian ini adalah untuk menambah pengetahuan dan membuka wawasan, disamping teori yang telah diperoleh di dalam kurikulum dan materi perkuliahan, sehingga mahasiswa memahami alur dalam proses kerja audit yang terjadi di lapangan. Metode presentasi dan pendampingan digunakan dalam pelaksanaan kegiatan pengabdian ini. Materi pelatihan dan praktik audit dilaksanakan oleh tim pengabdian serta praktisi audit (auditor) dari KAP yang berafiliasi dengan KAP big four menggunakan aplikasi virtual meetings yaitu zoom. Hasil dari pelatihan ini menunjukkan bahwa setelah diberikan pelatihan yang berkaitan dengan profesi akuntan, praktik kerja audit dan kualitas audit, mahasiswa mampu mengisi lembar aktivitas berupa kasus yang menjadi tolok ukur peningkatan pengetahuan mahasiswa akan praktik kerja audit.
\end{abstract}

Kata kunci: Pelatihan Audit; Kualitas Audit; Praktik Kerja Audit

\section{Kutipan:}

Gozali, E, O, D., Yusnaini, Y, Hamzah, R, S., \& Khamisah, N. (2021). Pelatihan Praktik Kerja Audit (Kualitas Audit) oleh Kantor Akuntan Publik (KAP) bagi Mahasiswa Jurusan Akuntansi, Fakultas Ekonomi Universitas Sriwijaya. Sricommerce: Journal of Sriwijaya Community Services, 2(1): 7-16. DOI: https://doi.org/10.29259/jscs.v2i1.26

\section{PENDAHULUAN}

Dalam UU RI Nomor 5 tahun 2011 tentang Akuntan publik, akuntan publik merupakan suatu profesi yang jasa asurans dan hasil pekerjaannya digunakan secara luas oleh publik sebagai salah satu pertimbangan penting dalam pengambilan keputusan (Kementerian Keuangan, 2011). Akuntan publik mengemban kepercayaan masyarakat untuk memberikan opini atas laporan keuangan atau informasi lainnya yang diterbitkan oleh suatu entitas. Masyarakat dalam memperoleh informasi keuangan perusahaan yang andal sebagai dasar pengambilan keputusan membutuhkan profesi akuntan publik untuk menaikkan tingkat keandalan laporan keuangan perusahaan tersebut. Dalam praktiknya, KAP memiliki indikator dalam melaksanakan proses audit yang berkualitas, dikenal dengan kualitas audit. Kualitas audit yang tinggi dari sebuah KAP mengindikasi bahwa KAP tersebut akan menghasilkan laporan audit yang berkualitas. Oleh karena itu, sebuah perusahaan akan mencari KAP dengan kualitas audit yang baik untuk mengaudit laporan keuangan perusahaan mereka.

Manajemen dengan pertimbangan dari komite auditnya memilih suatu KAP bagi perusahaannya. Dalam suatu perusahaan, Manajemen memegang peran penting bagi internal perusahaan, sedangkan komite audit adalah komite yang dibentuk oleh dan bertanggung jawab 
kepada Dewan Komisaris dalam membantu melaksanakan tugas dan fungsi Dewan Komisaris. Dengan kata lain, komite audit merupakan perpanjangan tangan dari dewan komisaris dalam melakukan pengawasan terhadap direksi yaitu pihak internal perusahaan. Sehingga, dalam proses penyeleksian KAP, keberadaan komite audit lebih independen dibandingkan pihak manajemen. (Arens, Randal \& Mark, 2008).

Perguruan tinggi sebagai tempat untuk menimba ilmu, tidak hanya memberikan mahasiswanya ilmu berupa teori, tetapi juga berupa keterampilan dalam praktik. Pelatihan secara praktik adalah penerapan seorang mahasiswa pada dunia kerja nyata yang sesungguhnya, yang bertujuan untuk mengembangkan keterampilan dan etika pekerjaan, serta mendapatkan kesempatan dalam menerapkan ilmu pengetauan dan keterampilan yang sudah dipelajari di perkuliahan. Selain itu, Pelatihan praktik juga bermanfaat untuk mengasah softskill dan interaksi mahasiswa terhadap lingkungan dunia kerja (Fauzi, 2016).

Dewasa ini, mahasiswa strata 1 di perguruan tinggi lebih banyak mengabiskan metode pembelajaran secara konsep dan teori. Memang tidak dipungkiri jika para mahasiswa tersebut menjadi paham konsep dan teori secara matang sebelum terjun ke dunia praktik. Sedangkan, realita yang dihadapi di masa ini, teori saja tidak cukup untuk menguasai suatu bidang keahlian tertentu. Dibutuhkan praktik yang setidaknya mendekati praktik nyata untuk lebih memberikan gambaran tentang bagaimana ilmu yang mereka pelajari dapat diaplikasikan. Praktik tersebut dapat berupa simulasi tentang suatu kasus yang sering dihadapi pada dunia praktik yang kemudian dikondisikan di dalam kelas pada saat pembelajaran berlangsung.

Dalam kegiatan pengabdian ini, sasaran ditujukan kepada mahasiswa jurusan Akuntansi Fakultas Ekonomi Universitas Sriwijaya (FE Unsri) yang sudah atau akan mengambil kekhususan audit. Oleh karena itu, pengabdian ini terkait dengan pelatihan praktik kerja di bidang audit bagi pelaku audit, yaitu auditor. Pelatihan praktik kerja pada auditor ini dihubungkan dengan kualitas audit yang menjadi dasar bagi auditor dalam melaksanakan proses audit. Kegiatan pelatihan ini selain diisi oleh tim pengabdian juga dipandu langsung oleh dua orang praktisi (auditor) di KAP Indonesia yang berafiliasi dengan KAP big four, sehingga dari segi mutu audit tidak diragukan lagi keabsahannya.

Berdasarkan survei yang telah kami lakukan sebelum pelaksanaan sosialisasi di awal kegiatan, mahasiswa di jurusan Akuntansi FE Unsri sebagian besar masih memiliki pengetahuan yang terbatas mengenai profesi akuntan, sehingga belum bisa membedakan profesi apa saja yang termasuk akuntan. Maka dari itu, mereka belum belum mengetahui secara mendalam apa itu profesi auditor dan bagaimana proses audit pada praktiknya dilaksanakan yang dimulai dari perencanaan awal sampai dengan terbitnya laporan audit. Kegiatan di dalam pengabdian ini memfasilitasi proses pembelajaran praktik audit tersebut. Selain itu, kegiatan ini berjalan beriringan dengan kegiatan penelitian yang dilaksanakan pada objek dan subjek yang sama. Sehingga kegiatan pengabdian kepada masyarakat yaitu mahasiswa FE Unsri dapat memberikan nilai tambah yaitu pengetahuan tentang praktik audit dan kualitas audit dalam suatu proses audit.

\section{STUDI PUSTAKA}

Keputusan Menteri keuangan (KMK) No.423/KMK.06/2002 tentang Jasa Akuntan Publik, menyebutkan bahwa KAP hanya boleh mengaudit klien yang sama maksimal 5 tahun berturut-turut. Hal ini dikarenakan KAP yang memiliki hubungan yang cukup panjang dapat meningkatkan kecenderungan relasi yang erat sehingga dapat menurunkan independensi (Joshi et al., 2009). Sebagai contoh, kasus kejahatan akuntansi yang terkenal di awal tahun 2000-an yaitu kasus Enron yang mengakibatkan kongres AS mengeluarkan sebuah aturan yang diberi nama "The SarbanesOxely Act 2002".

SOX act ini adalah sebuah peraturan yang ditujukan kepada perusahan-perusahaan terbuka 
yang sahamnya diperdagangkan di bursa saham AS. Lebih lanjut, peraturan ini bertujuan untuk melindungi investor atas perusahaan-perusahaan terbuka tersebut, dengan memaksa perusahaanperusahaan tersebut untuk memperbaiki pengungkapan laporan keuangannya. Berkaca pada kasus Enron, kejahatan akuntansi yang terjadi melibatkan KAP yang mengauditnya yang mengakibatkan KAP tersebut ditutup dan dicabut izin auditnya. Oleh karena itu, penting bagi pihak manajemen dengan pengawasan dari komite audit untuk memilih KAP dengan kualitas yang tinggi.

\subsection{Teori Pilihan Rasional}

Coleman (2013) menjelaskan bahwa teori pilihan rasional mengarah pada tindakan perseorangan mengarah pada suatu tujuan dan tujuan tersebut adalah tindakan yang ditentukan oleh nilai atau preferensi (pilihan). Coleman menyatakan bahwa memerlukan konsep tepat mengenai aktor rasional yang berasal dari ilmu ekonomi yang melihat aktor memilih tindakan yang dapat memaksimalkan kegunaan ataupun keinginan serta kebutuhan mereka. Ada dua unsur utama dalam teori Coleman, yaitu aktor dan juga sumber daya. Sumber daya adalah setiap potensi yang ada atau yang dimiliki, sedangkan aktor yaitu seseorang yang melalukan tindakan yang dalam hal ini disebut oleh klien KAP. Klien KAP melakukan tindakan pengambilan pilihan secara rasional ketika akan memilih KAP tertentu yang difokuskan pada terjaganya kepentingan perusahaan.

\subsection{Teori Pengambilan Keputusan}

Suatu model pengambilan keputusan didasarkan pada perilaku manusia untuk memilih dengan asumsi mengoleksi, memproses dan menginterpretasikan informasi untuk mendapatkan alternative yang paling efisien (Etzioni, 2010). Oleh karena itu, suatu entitas (klien) dalam hal pengambilan keputusan dalam kegiatan ini apakah sebagai pihak manajemen atau komite audit harus membuat keputusan akan bekerjasama dengan siapa dan apa yang bisa didapatkan oleh perusahaan terkait hal itu, yang pada akhirnya perusahaan atau entitas tersebut menentukan KAP mana yang akan dipilih sebagai partner dalam menunjang bisnisnya.

\subsection{Kualitas Audit}

International Federation of Accountants (IFAC) tahun 2014 menerbitkan A Framework for Audit Quality yang memuat suatu panduan bagi anggotanya dalam rangka mendorong peningkatan kualitas audit secara global (Institut Akuntan Publik Indonesia, 2016). Dalam framework tersebut dijelaskan bahwa IFAC menjelaskan elemen kunci pada level perikatan, level KAP, dan level nasional yang relevan dengan kualitas audit. IFAC juga menggarisbawahi bahwa elemen kunci kualitas audit terletak pada level perikatan dan level KAP yang meliputi input, proses, dan output. IFAC juga menekankan kualitas audit dipengaruhi oleh pola hubungan dan pemahaman pentingnya kualitas audit diantara berbagai pihak, yaitu auditor, manajemen, komite audit, pihak yang bertanggung jawab atas tata kelola, pengguna serta regulator. Pihak-pihak tersebut diharapkan dapat mendorong peningkatan kualitas audit melalui peran dan fungsi masing-masing pihak tersebut. Indikator kualitas audit adalah suatu indikator kunci yang memungkinkan suatu audit yang berkualitas dilaksanakan secara konsisten oleh Akuntan Publik melalui KAP sesuai dengan standar profesi dan ketentuan hukum yang berlaku.

Audit dikatakan berkualitas apabila dalam pelaksanaan audit tersebut berhasil membuat perencanaan yang jelas, prosedur dan job allocation yang terstruktur, mampu merumuskan dan mengidentifikasi risiko audit dengan jelas dan benar, dilakukan sesuai dengan prosedur dan aturan pengauditan serta hukum yang berlaku, sehingga hasilnya dapat digunakan untuk mengambil keputusan bagi pihak perusahaan dan shareholder. Diasumsikan bahwa Kualitas audit merujuk kepada tingkatan seorang auditor itu percaya bahwa laporan keuangan itu tidak mengandung salah saji setelah selesainya pekerjaan audit (Wedemeyer, 2010)

Kerangka audit terdiri atas beberapa unsur yaitu input, process, output, siklus pelaporan 
keuangan dan faktor kontekstual yang terdapat dalam The International Auditing and Assurance Standards Board (IAASB) tahun 2014. Input, process dan output merupakan tiga aspek fundamentalnya. Dijelaskan bahwa Keterampilan (skill), pengalaman auditor, atribut dari personel dalam audit, nilai etis, pola pikir (mindset) dapat diklasifikasikan sebagai input. Output umumnya berpengaruh secara langsung terhadap kualitas audit karena output merupakan hasil (outcome) dari sebuah proses audit, sehingga dijadikan pertimbangan bagi stakeholder dalam mengambil keputusan. Output dapat meliputi laporan audit, hasil inspeksi, dan hasil lain yang terjadi terkait proses audit setelah proses tersebut terselesaikan (PCAOB, 2013).

\section{METODE}

Kegiatan ini dilaksanakan setelah rangkaian kegiatan penelitian dengan judul yang bersesuaian dengan pengabdian ini. Pengabdian ini dilaksanakan secara virtual meeting melalui aplikasi Zoom, dikarenakan adanya pandemi covid-19 yang telah mewabah di Kota Palembang. Kegiatan ini dilaksanakan selama tiga hari pada tanggal 6, 7, dan 8 November 2020. Khalayak dari kegiatan pengabdian kepada masyarakat ini adalah seluruh Mahasiswa Strata 1 Jurusan Akuntansi FE Unsri semester 5 dan 7 pada kelas Indralaya dan Palembang.

Kegiatan hari pertama dimulai dengan sosialisasi dan penyuluhan kegiatan pengabdian ini dengan memberikan informasi mengenai jadwal kegiatan dan penjelasan umum mengenai tujuan dan manfaat dari kegiatan ini. Selanjutnya, survei awal dilaksanakan dengan menyebarkan link google form yang diisi oleh peserta kegiatan yaitu mahasiswa Akuntansi FE Unsri yang digunakan untuk mengetahui pemahaman peserta mengenai profesi akuntansi, proses audit dan kualitas audit. Setelah itu, dilakukan pendampingan kepada mahasiswa melalui sesi tanya jawab untuk memastikan bahwa materi yang telah diberikan pada hari pertama pelatihan telah dipahami dengan baik.

Pada hari kedua, diawali dengan sosialisasi kegiatan yang dilanjutkan dengan praktik berupa simulasi kasus yang diberikan kepada para peserta. Peserta dibagi menjadi dua kelompok untuk mendiskusikan kasus yang diberikan, kemudian dibimbing untuk menyelesaikan kasus tersebut. Kelompok tersebut yaitu kelompok kelas eksperimen dan kelompok kelas kontrol. Kedua kelas tersebut mendapatkan perlakuan yang berbeda pada setiap pertemuan. Kedua kelas tersebut terbagi lagi menjadi dua peran, yaitu peran sebagai manajemen keuangan dan peran sebagai komite audit di suatu perusahaan yang bertugas untuk memilih satu di antara dua KAP yang akan mengaudit perusahaan tersebut. Pada kelompok kontrol, tidak diberikan perlakukan pemahaman indikator kualitas audit, sedangkan kelas eksperimen diberikan perlakukan pemahaman indikator kualitas audit yang dikupas tuntas satu per satu (10 indikator kualitas audit) dan dikelompokkan berdasarkan input dan outputnya. Pemahaman indikator audit diberikan melalui materi yang disampaikan oleh instruktur kelas dan juga praktisi yang merupakan auditor di KAP big four, sehingga pemahaman indikator audit dikaitkan langsung dengan simulasi audit yang terjadi pada praktiknya. Proses pendampingan dilakukan oleh kami selaku instruktur, yang dimulai dengan penjelasan masingmasing kasus dari kelompok-kelompok tersebut sampai dengan pemilihan KAP berdasarkan kualitas audit. Hari ketiga dilakukan dengan jadwal yaitu pembahasan terkait kasus yang diberikan oleh masing-masing kelompok, lalu dilanjutkan dengan sesi diskusi dan tanya jawab dalam membahas hasil pemilihan KAP dari kasus tersebut. Kegiatan ditutup dengan monitoring dan evaluasi dengan menyebarkan link google form kepada para peserta, yaitu mahasiswa Akuntansi FE Unsri. 


\section{HASIL DAN PEMBAHASAN}

Pelaksanaan kegiatan pengabdian ini dilaksanakan selama tiga hari pada tanggal 6, 7 dan 8 November 2020 menggunakan aplikasi virtual meeting Zoom. Kegiatan ini diikuti oleh 50 orang peserta yang merupakan mahasiswa jurusan Akuntansi FE Unsri. Para peserta pelatihan merupakan mahasiswa yang telah atau akan memilih kekhususan audit.

Berdasarkan data responden diketahui bahwa rata-rata mahasiswa yang menjadi peserta kegiatan ini adalah mahasiswa angkatan 2017 atau semester V. Pada semester tersebut, mereka telah mendapatkan mata kuliah Pengauditan I, sehingga mereka telah memiliki pengetahuan dasar tentang pengauditan. Seluruh peserta adalah mahasiswa yang telah atau akan mengambil kekhususan audit. Terdapat 23 orang berasal dari kampus Palembang sedangkan 27 orang lainnya berasal dari kampus Indralaya dengan rata-rata IPK peserta adalah 3,45.

Kegiatan hari pertama dibuka dengan pengisian formulir oleh para peserta yang berisikan pertanyaan mengenai pemahaman profesi audit, praktik audit dan kualitas audit. Selanjutnya, presentasi dari tim pengabdian yang disampaikan langsung oleh ketua dan anggota pengabdian. Materi yang disampaikan terkait dengan profesi akuntan yang dilanjutkan dengan pendalaman mengenai praktik audit yang dihubungkan dengan kualitas audit. Sebagai dampak dari adanya pandemi Covid-19, pelaksanaan pelatihan ini menggunakan virtual meeting melalui aplikasi Zoom, sehingga proses koordinasi antara peserta dan tim pengabdian dilakukan menggunakan whatsappgroup dan google classroom. Materi dan modul pelatihan dibagikan melalui kedua aplikasi tersebut. Penyampaian materi mengenai profesi akuntan disampaikan oleh tim pengabdian, selanjutnya materi mengenai proses dalam praktik audit dan kualitas audit disampaikan oleh dua orang praktisi dari KAP yang berafiliasi dengan KAP big four, yaitu Khoirunnisa dan Renoley. Kegiatan ini terlaksana dengan baik ditandai dengan antusiasme para peserta dalam mengajukan pertanyaan terkait materi yang diberikan.

Gambar 1. Dokumentasi pelatihan hari pertama

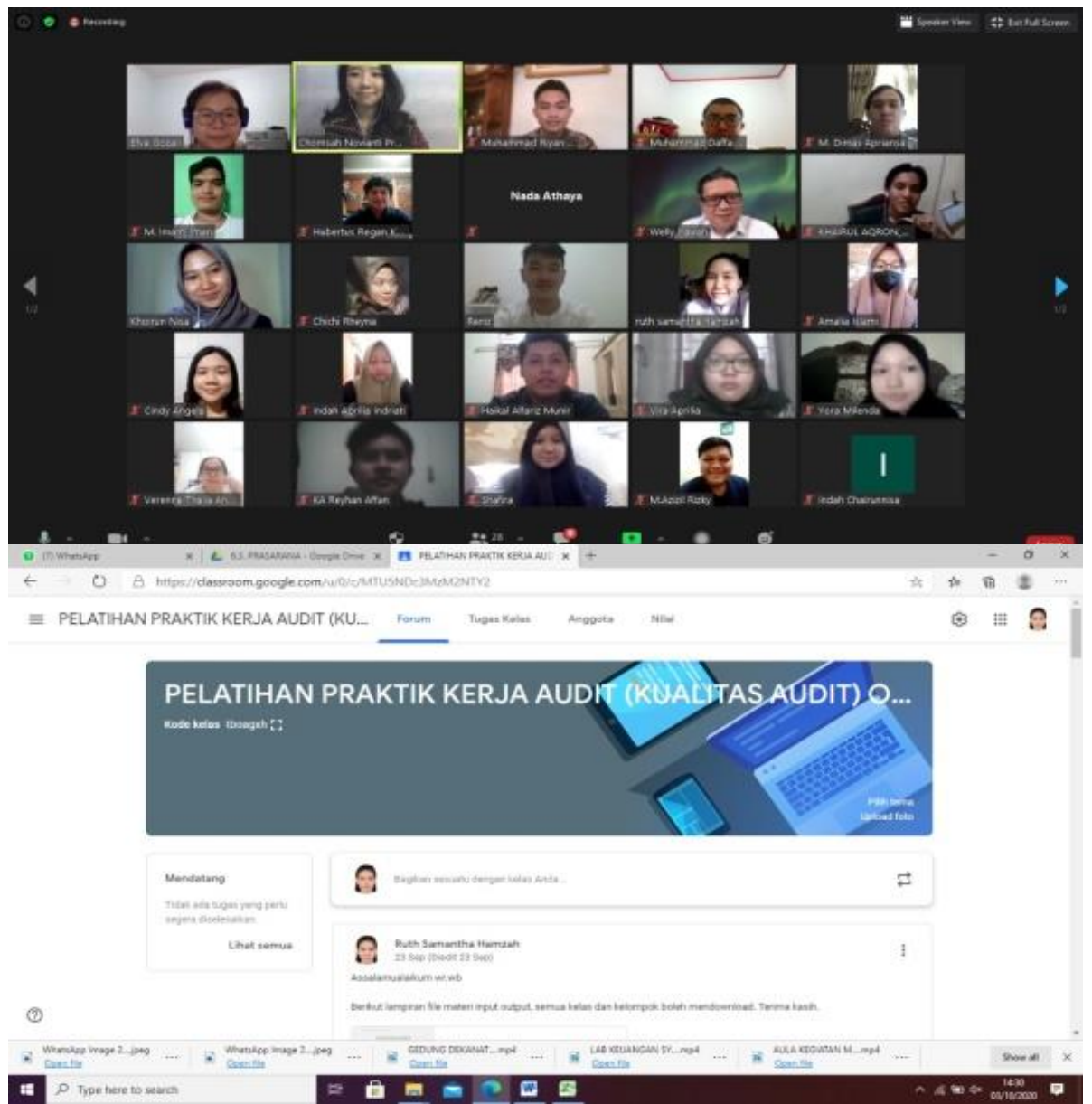




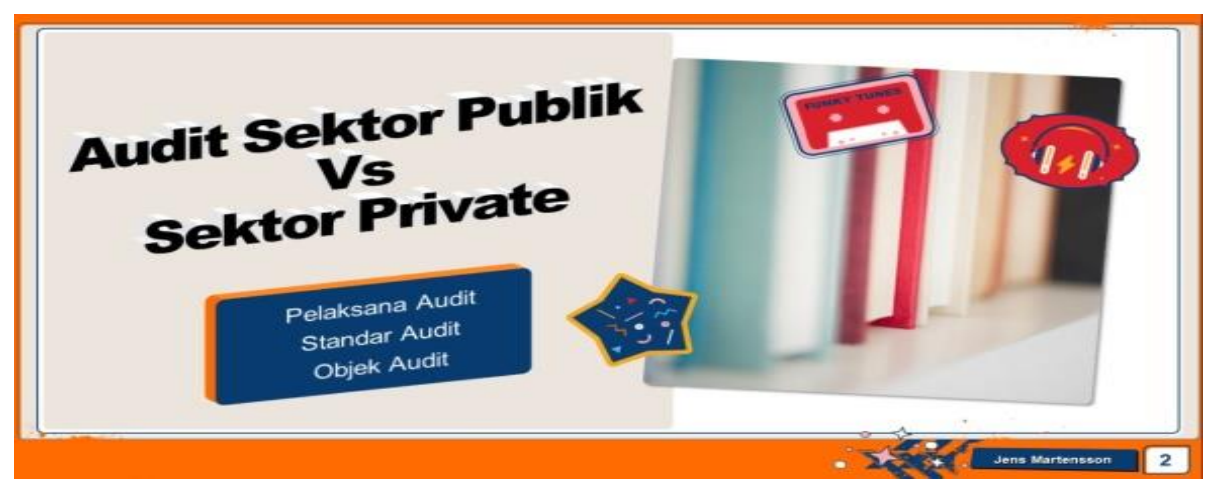

Pada kegiatan hari kedua dan ketiga, yang dilaksanakan pada jam yang sama dengan hari pertama, dimulai dengan membagikan lembar aktivitas bagi para peserta yang berisikan kasus. Lembar aktivitas tersebut memuat kasus yang disesuaikan dengan materi dalam pelatihan di hari pertama, yang difokuskan pada proses praktik audit dengan kualitas audit yang diisi secara individual oleh para peserta. Proses pengisian lembar aktivitas tersebut dibimbing oleh tim pengabdian, sehingga para peserta bebas untuk bertanya apabila ada yang mengalami hambatan maupun kesulitan. Kegiatan hari kedua juga dilakukan dengan pembagian kelompok eksperimen dan kontrol serta penjelasan pengerjaan. Lanjut dengan aktivitas hari ketiga, dimana aktivitas yang dilakukan adalah pembahasan kasus dari dua kelompok yaitu eksperimen dan kontrol yang masingmasing berperan sebagai manajemen maupun komite audit (total kelompok menjadi 4 kelompok) yaitu dua kelompok ekperimen baik peran manajemen dan peran komite audit di hari kedua, serta dua kelompok kontrol (peran manajemen maupun komite audit) di hari ketiga, sehingga hasil akhir adalah seluruh peserta mampu menyelesaikan lembar aktivitas dengan baik. Untuk menutup kegiatan di hari ketiga, formulir berisi pertanyaan yang sama dengan formulir yang disebarkan sebelum aktivitas di hari pertama disebarkan kembali, dan para peserta diharapkan mengisi formulir tersebut yang dikirimkan melalui link google form. Setelah seluruh peserta mengisi formulir tersebut, tim pengabdian mengevaluasi hasilnya dan membandingkannya dengan formulir yang disebarkan pertama kali.

\section{Gambar 2. Dokumentasi hari kedua}

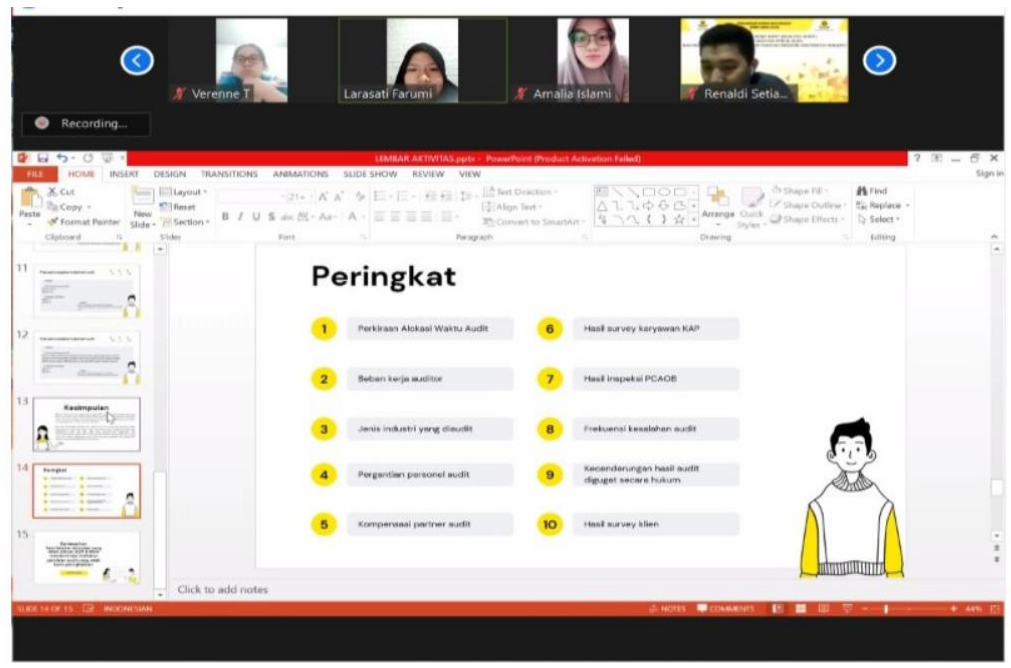




\section{Gambar 3. Dokumentasi Hari ketiga}
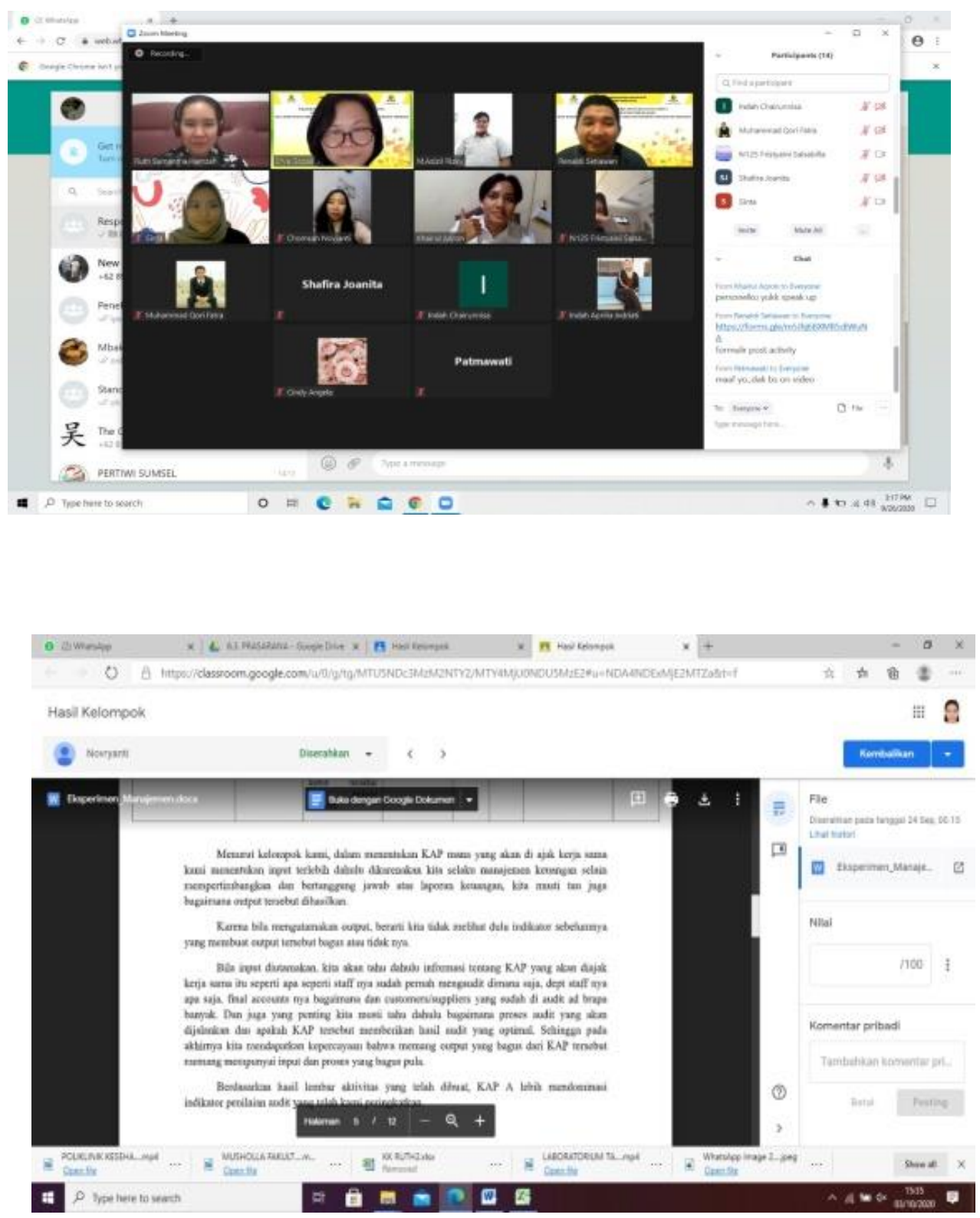

Hasil akhir yang diharapkan dari kegiatan pengabdian ini adalah para peserta yang merupakan mahasiswa jurusan Akuntansi FE Unsri dapat memahami profesi dari akuntan karena nantinya mereka sebagai alumni jurusan Akuntansi FE Unsri sudah selayaknya menekuni profesi yang sesuai dengan keilmuannya yaitu sebagai akuntan yang berkualitas. Selanjutnya, secara kekhususan mereka telah memilih kekhususan mata kuliah audit sehingga mereka wajib memahami alur di dalam proses audit, dan jika mereka memahami praktik audit yang terjadi di lapangan, mereka akan memiliki pengetahuan dan kemampuan tambahan tentang ilmu pengauditan selain teori. Maka dari itu, sudah merupakan hal yang lumrah jika mereka mengetahui apa saja kaitan indikator-indikator kualitas audit di dalam praktik audit.

Beragam pengukuran dapat digunakan dalam kualitas audit untuk memastikan bahwa pelaksanaan audit oleh auditor khusunya auditor eksternal dilaksanakan dengan kualitas yang baik yang tidak terbatas hanya pada output yang dihasilkan, tetapi juga mempertimbangkan faktor input di dalamnya. Berdasarkan rekapitulasi hasil formulir sebagai evaluasi untuk menilai pemahaman yang diperoleh dari pelatihan ini, dapat diketahui bahwa para peserta telah mengalami peningkatan 
pengetahuan tentang profesi akuntan, praktik audit dan kualitas audit yang dirangkum dalam tabel berikut:

Tabel 1.

Penilaian Hasil Kegiatan

\begin{tabular}{lrr}
\hline & pra aktivitas & \multicolumn{1}{c}{ pasca aktivitas } \\
\hline Rata-rata Total & 13,20408 & 22,04 \\
\hline Rata-rata Individu & 2,20068 & 3,673333 \\
\hline
\end{tabular}

Evaluasi hasil kegiatan dilakukan dengan menyebarkan formulir berisi enam pertanyaan mengenai profesi akuntan, praktik audit dan kualitas audit kepada seluruh peserta yang berjumlah 50 orang. Keenam pertanyaan tersebut memiliki rentang nilai antara 1-4, dimana 1=tidak paham; 2=kurang paham; 3=paham; dan 4=sangat paham. Nilai rata-rata per individu sebelum pelaksanaan aktivitas adalah 2,2 yang mengindikasi bahwa rata-rata peserta belum memahami tentang profesi akuntan, praktik audit dan kualitas audit, sedangkan nilai rata-rata tiap peserta meningkat setelah pelatihan praktik audit selesai dilaksanakan yang ditunjukkan dengan nilai rata-rata peserta adalah 3,67 . Nilai tersebut mengindikasi bahwa pengetahuan dan kemampuan peserta telah mendekati sangat paham. Sehingga, hasil evaluasi inilah yang dijadikan tolok ukur keberhasilan dari kegiatan pengabdian ini. Pengabdian yang kami lakukan ini sejalan dengan yang dilakukan olah Dickins et al (2018) dan Aghazadeh dan Hoang (2020), bahwa kesepuluh indikator audit yaitu beban kerja auditor, bidang keahlian, audit turnover, waktu audit, hasil survei kepuasan karyawan, gaji partner audit, hasil survei akan kepuasan klien, hasil inpeksi PCAOB, kesalahan dalam opini audit, dan tuntutan hukum layak dijadikan pengukuran untuk mengetahui kualitas audit dari suatu KAP dalam rangka memilih satu KAP yang dianggap paling tepat bagi perusahaan yang dipilih oleh masingmasing peran yaitu manajemen keuangan dan komite audit.

\section{KESIMPULAN}

Kegiatan pengabdian pelatihan praktik kerja audit dan kualitas audit bagi mahasiswa jurusan Akuntansi FE Unsri yang dilaksanakan pada bulan November 2020 dapat disimpulkan bahwa sebagian besar mahasiswa jurusan Akuntansi FE Unsri belum memahami sepenuhnya apa saja profesi dari akuntan, bagaimana proses audit dalam praktik dan apa saja kualitas audit yang mempengaruhi praktik audit. Hasil kegiatan pengabdian ini memberikan pengetahuan dan kemampuan tambahan kepada mahasiswa jurusan Akuntansi FE Unsri dalam memahami praktik audit dan kualitas audit. Dengan adanya kegiatan pengabdian ini, mahasiswa jurusan Akuntansi FE Unsri memahami pentingnya pemahaman dalam praktik audit dan kualitas audit yang nantinya dapat mereka terapkan setelah memasuki dunia kerja.

Adapun saran dari kegiatan pengabdian ini adalah kegiatan pelatihan yang dilaksanakan melalui virtual meeting memiliki beberapa kendala terkait keterbatasan koneksi dan jaringan internet, sehingga kegiatan yang dilaksanakan secara online tidak dapat berjalan maksimal seperti halnya pelatihan tatap muka. Namun kendala tersebut tetap tidak mengurangi esensi dari kegiatan pengabdian ini. Selanjutnya, diharapkan para peserta kegiatan ini tetap meningkatkan kemampuan dan pengetahuan mereka tentang praktik audit terutama yang terkait dengan teknologi.

\section{UCAPAN TERIMA KASIH}

Kegiatan Pengabdian ini didanai oleh PNBP Fakultas Ekonomi Universitas Sriwijaya. Terima kasih kepada panitia dan warga desa yang telah berpartisipasi dalam pelaksanaan kegiatan ini. 


\section{REFERENSI}

Aghazadeh, S., \& Hoang, K. (2020). How does audit firm emphasis on client relationship quality influence auditors' inferences about and responses to potential persuasion in client communications? Accounting, Organizations and Society, xxxx, 101175. https://doi.org/10.1016/j.aos.2020.101175

Arens, Randal dan Mark. 2008. Auditing dan Jasa Assurance (Pendekatan Terintegrasi). Edisi Kedua belas. Jilid 1. Jakarta: Penerbit Erlangga

Coleman, James S. (2013). Dasar-dasar Teori Sosial Foundation of Social Theory. Bandung: Nusa Media.

Dickins, D., Johnson-Snyder, A. J., \& Reisch, J. T. (2018). Selecting an auditor for Bradco using indicators of audit quality. Journal of Accounting Education, 45(July), 32-44. https://doi.org/10.1016/j.jaccedu.2018.07.001

Etzioni, A. (2010). Behavioral economics: A methodological note. Journal of Economic Psychology, 31(1), 51-54. https://doi.org/10.1016/j.joep.2009.09.004

Fauzi, Yuliana. (2016). BPS: Jumlah Pengangguran di Indonesia Menciut 530 Ribu Orang. http://m.cnnindonesia.com/ekonomi/20161107152144-92-170923/bps-jumlahpengangguran-di-indonesia-menciut-530-ribu-orang/ diakses tanggal 10 November 2020.

Institut Akuntan Publik Indonesia. (2016). Draf Panduan Indikator Kualitas Audit Pada Kantor Akuntan Publik.

Joshi, P. L., Ajmi, J. Al, \& Bremser, W. G. (2009). A study of auditor-client relationships and problems in the Bahraini audit environment. Advances in Accounting, 25(2), 266-277. https://doi.org/10.1016/j.adiac.2009.08.003

Kementerian Keuangan. (2011). Undang-Undang RI Nomor 5 tahun 2011 tentang Akuntan Publik. https://jdih.kemenkeu.go.id/fullText/2011/5TAHUN2011UU.HTM diakses tanggal 10 November 2020.

PCAOB. (2013). Standing Advisory Group Meeting Discussion - Audit Quality Indicators. Standing Advisory Group Meeting Discussion - Audit Quality Indicators, 202, 1-34.

Wedemeyer, Phil D. (2010). A discussion of Auditor Judgement As The Critical Component in Audit Quality-A Practitioner's Perspective. International Journal of Disclosure and Governance 7 (4). Doi: $10.1057 /$ idg.2010.19 